\title{
長期臥床により嚥下障害を呈した超高齢患者の曣下訓練経過
}

\author{
一一喉頭挙上介助法を使った嚥下訓練の有効性について—
}

\author{
山本真由美
}

要 約:長期臥床により誤嚥性肺炎を繰り返していた超高齢患者に対して嚥下訓練を実施し, 経口摂取が可能になり退院後も嚥下機能が長期間維持された症例を経験した。この症例におい て, 嚥下訓練の早期開始, 喉頭挙上介助法を使った嚥下訓練, 退院に向けての家族指導の 3 点 が有効だったと考える，嚥下反射が安静時に観察されない状態だったので，嚥下訓練の早期開 始はさらなる誤嚥と嚥下機能の悪化を止めたと考える。嚥下訓練においては, 喉頭を他動的に 押し上げて維持する喉頭挙上介助法が本症例の燕下反射誘発に有効だった。嚥下反射は中枢性 のパターン運動であり，喉頭挙上維持はパターン運動開始のトリガーになるのではないかと考 えた，退院にあたっては，家族に対して口腔顔面筋群の筋力向上訓練，食事形態，食事介助の 指導を行ったが, これは退院後の嚥下機能維持と誤嚥防止に有効だった。

索引用語：喉頭挙上介助法, 嚥下訓練, 嚥下障害, 廃用症候群, 超高齢患者

\section{Progress of Dysphagia Therapy for Oldest-Old Patient Confined to Bed over a Long Period \\ -Effectiveness of Dysphagia Therapy Using the Help Method \\ by Elevating the Larynx -}

Mayumi Yamamoto

\begin{abstract}
This study reports on the progress of dysphagia therapy performed for an oldest-old patient who has been confined to bed over a long period, and who has contracted aspiration pneumonia repeatedly. As a result of the therapy, the patient became able to ingest and his swallowing function was preserved for about one year and a half after discharge. Progress pointed to three effective points: early beginning of the therapy; dysphagia therapy using the help method by elevating the larynx; explanation to his family before discharge. The therapy was begun on the third day after admission. If the therapy had not been introduced early, aspiration would have continued further and swallowing function would have worsened. The help method of elevating the larynx was useful for triggering the swallowing reflex in this case. This method preserves elevation of the larynx by pushing up the larynx transitively. As the swallowing reflex is a central pattern movement, it is suggested that preservation of larynx elevation triggers central pattern movement. Before discharge, it was necessary to explain to the patient's family about oral
\end{abstract}

\footnotetext{
市立砺波総合病院総合リハビリテーションセンター：テ939-1395 富山県砺波市新富町 1-61
} 
motor exercise for muscular strength preservation, appropriate food texture, and help for feeding. These explanations were useful to preserve his swallowing function.

Key words: help method by elevating the larynx, dysphagia therapy, dysphagia, disuse syndrome, oldest-old patient

\section{緒言}

老年医学では，高齢者の定義は 65 歳以上，そのな かで 75 歳以上を後期高齢者, 85 歳以上または 90 歳 以上から超高齢者とする，というのが現在の考え方で あり，また世界的なコンセンサスである1). 65〜74 歳 の前期高齢者では個体の老化の徵候が明瞭になってき ており，いわゆる老年疾患に罹患する人の数も増えて くるが，日常生活に大きく差し支える機能障害を有す る率はまだ低く，元気で活動的な人が多い。これに対 し，75〜89 歳の後期高齢者，90 歳以上の超高齢者で は老化の徵候はさらに明瞭となり, 複数の疾病を抱え る人が著しく増加する。一方, 種々の原因で起こる䛊 嚥，転倒，認知機能障害，尿流障害（尿失禁）といっ た症候も急増する。このうち誤嚥（嚥下機能障害）は, 脳血管障害, 意識障害, パーキンソン病, 悪性疾患の 末期や ADL の低下した長期臥床患者などさまざまな 病態において生じ, 誤嚥性肺炎やびまん性嚥下性細気 管支炎を起こす2)。したがって後期高齢者や超高齢者 における嚥下機能障害は, 複数の疾病や後遺症を背景 に抱えていることが多く，前期高齢者に比して訓練に よる改善を得にくい, 経口摂取を断念し, 経管栄養を 選択する場合も多い. しかし，超高齢となっても栄養 は経口摂取によることが望ましく，嚥下機能改善は QOL の維持や生命予後のために重要である.

今回, 長期臥床により誤嚥性肺炎を繰り返していた 超高齢患者に対し嚥下訓練を実施し，経口摂取および 自宅退院が可能となった症例を経験した，そして退院 後も嚥下機能が長期間維持された。 その嚥下訓練経過 と, この症例に対して有効であったと考えられる喉頭 挙上介助法について報告する。

\section{訓練 方 法}

まず，口腔顔面筋群の筋力向上訓練と嚥下機能向上 訓練を行い，嚥下反射が十分な喉頭挙上を伴って自発 的に，あるいは介助によって容易に起こるようになっ てから, 直接嚥下訓練を行った. 訓練の頻度は 1 日 1 回, 月曜から金曜の週 5 回である.

\section{1 . 口腔顔面筋群の筋力向上訓練}

ベッド上で 45 度ギャッジアップし, 枕やクッショ ンを用いて頸部を前屈位に, 体幹を正中位に保持して, 下顎下制·挙上，口唇突出·引き，舌突出·左右口角· 左右煩部 - 口腔外挙上· 口腔内挙上, 舌打ち, 㚘部ふ くらまし・すぼめを自発運動にて 10 回ずつ行わせる. 自発運動が困難な場合には，徒手による介助下に下顎 下制・挙上や口唇突出・引きを行わせる.

\section{2. 嚥下機能向上訓練}

直接嚥下訓練を行う前に, 喉頭挙上を介助しながら の空嚥下訓練から開始する。喉頭挙上介助法 ${ }^{3)}$ は, 喉 頭下部に手指を当てて喉頭を押し上げて嚥下反射を誘 発する手技である（図 1 ）。嚥下反射誘発後には，聴 診により咽喉頭の唾液貯留音の消失を確認する。

空嚥下が自発的に, あるいは介助によって容易に起 こることを確認した後，とろみ付の液体を使った直接 嚥下訓練を行う。とろみ付の液体を容易に嚥下するこ とが可能になったら，ゼリーによる嚥下訓練に移行す る。ゼリーの燕下が可能になったら，重度嚥下食（又 リ濑ゼリー, ゼリー状・マッシュ状の副菜）による嚥 下訓練を開始する，重度嚥下食の嚥下が可能になった ら軽度嚥下食（全张分・少し咀嚼が必要な柔らかさの副 菜）に変更する。なお，STによる嚥下訓練では朝食 もしくは昼食を用い，その食事形態が容易に摂取でき るようになってから他の 2 食の食事形態も変更する.

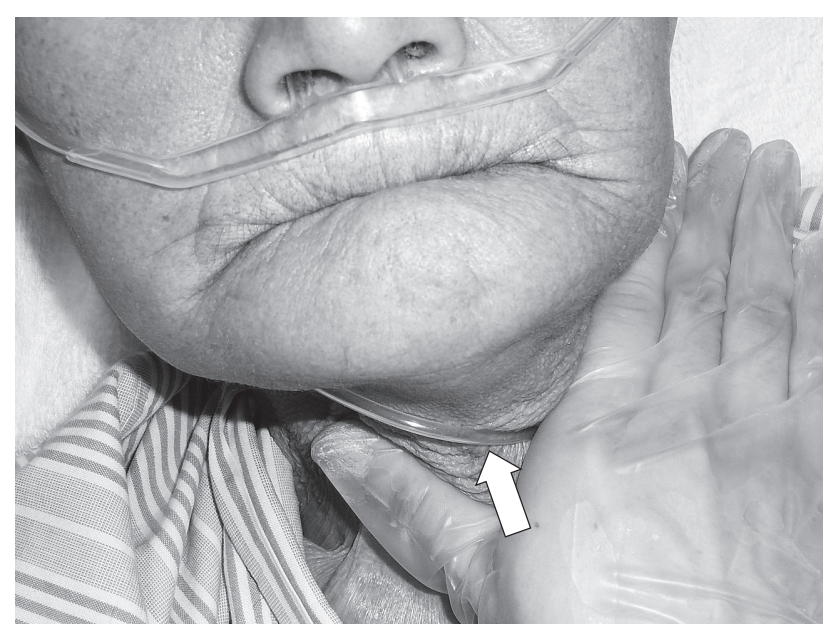

図 1 喉頭挙上介助法（文献 3 より） 


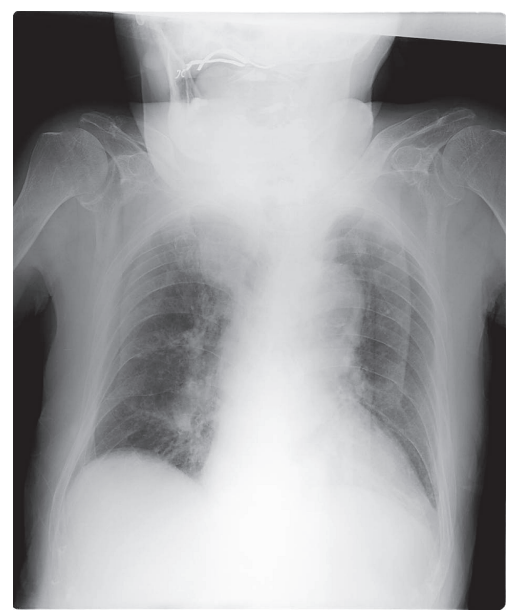

入院 1 日目. 右下肺浸潤影疑い.

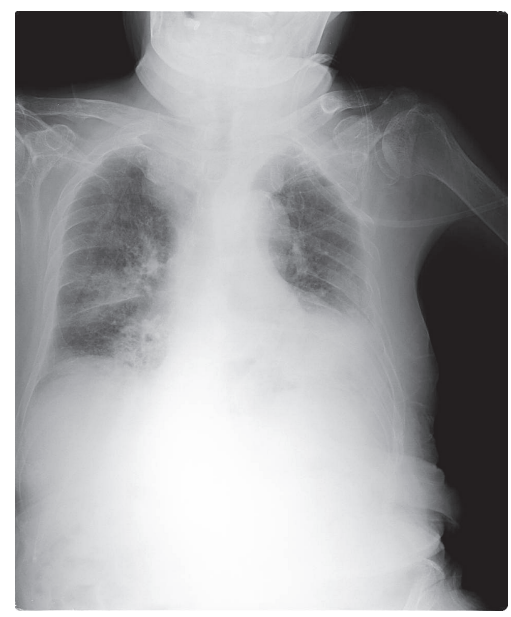

入院 3 日目(燕下訓練開始時)。右中肺 野浸潤影出現.

図 2 胸部X線

\section{症例}

97 歳, 男性.

既往歴：1986 年 6 月, 脳梗塞を発症し保存治療を 受けた。治療後, 軽度右片麻疩（Br. stage VI）は残っ たが，ADL は自立していた。 2000 年 9 月両眼白内障 のため入院した. 2002 年 12 月胸椎多発性圧迫骨折 で入院し, 退院後の身体機能は介助歩行に低下した. 2005 年 11 月，誤燕性肺炎で入院治療を受けたが，入 院中においても誤與性肺炎を繰り返し治療に長期間を 要した、リハビリについては理学療法のみが施行され, 見守りでベッド・車椅子間の移乗が可能になり, 2006 年 4 月に退院となった。

現病歴：2006 年 8 月に 38 度以上の発熱が見られ， 3 日後に当院を受診し入院した。誤嚥性肺炎の診断の 下，抗生物質が投与された。 入院 2 日目に食物が気 管から吸引されて絶食となり，3 日目にリハビリテー ション科に鱟下に関する依頼がなされた。
現症：入院時には血圧 $140 / 66$, 体温 $39.5^{\circ} \mathrm{C}$, $\mathrm{SpO}_{2}$ 90\%であった。臨床検査デー夕では CRP 9.12, 白血球数 $9.6 \times 10^{3}$ であった，入院 3 日目には体温は $38.5^{\circ} \mathrm{C}$ に下がったが, $\mathrm{SpO}_{2}$ は鼻腔カニューレからの 酸素吸入を $4 \mathrm{l} / \mathrm{min} に し て 90 \%$ 台になるという状態 だった。臨床検查データでは，CRP 17.99, 白血球数 $14.2 \times 10^{3}$ となった。胸部 X線像では, 右下肺と右中 肺野に浸潤影が認められた（図 2 ).

身体機能所見としては，介護保険の障害老人日常生 活自立度でランク C2 であったが，上下肢に明らかな 麻瘏, 筋緊張異常, 関節拘縮はなく, 自発運動が認め られた。コミュニケーション能力については, 言語指 示には従えたが，発語はなかった。発声持続時間は 1 〜2秒と短かった。咳嗽は随意的には行えなかった。 口腔周囲および口腔内所見については，安静時に右口 角はわずかに下垂していたが口唇閉鎖は可能であっ た，安静時に舌は右にわずかに偏位しており，舌運動 は口腔外挙上や左右煩部も可能だったが運動範囲の軽 度制限が見られた，㚘部運動はふくらましとすぼめが 可能だったが不十分だった。下顎・唇・軟口蓋の運 動範囲は正常であった. 口腔各器官の繰り返し運動は, 10 回続けることが困難で数回ごとに動きが止まると いう状態だった，與下機能については，口頭指示での 空苝下は 1 回のみで, 以後は自発的に起こらなかった。 そこで，喉頭を他動的に押し上げると嚥下反射は起こ り，その際の喉頭挙上は触診で確認したところ良好で あった。咽喉頭部の唾液貯留音は，常に認められてい た。

本症例に見られた運動障害は 2002 年の胸椎圧迫骨 折以後に低活動と臥床により進行した廃用と加齢によ るものと考えた。嚥下障害は 2005 年から認められる ようになったが，この頃は移乗が困難になり1日中卧 床するようになっていた。長期臥床による廃用性筋力 低下が䀻下関連筋にも及んだと考えた。

嚥下造影は, 発熱者, $\mathrm{SpO}_{2}$ が $90 \%$ 以下の者, 喀 痰が非常に多い場合, 座位でバイタルサインが安定 しない場合などは延期する ${ }^{4)}$. 初回嚥下評価時, 体温 $38.5^{\circ} \mathrm{C}, \mathrm{SpO}_{2}$ は酸素吸入を行って $90 \%$ 台となる状態 であり,また痰も非常に多く頻回な吸痰が必要だった。 鱟下反射は安静時に観察されず, 誤嚥の危険が高い状 態だった。そのため嚥下造影は実施しなかった。

\section{処置および経過}

口腔顔面筋群の筋力向上訓練と喉頭挙上を介助しな がらの空嚥下訓練から開始した。口腔顔面筋群の筋力 
向上訓練は易疲労のため休みながら行った，喉頭挙上 介助法を使って嚥下反射を誘発し聴診により咽喉頭の 唾液貯留音の消失を確認してから，とろみ付の液体を 使った直接嚥下訓練を開始した。このとき，嚥下反射 がすぐに起こることもあったが遅延したり起こらない こともあった，嚥下反射が起こらないときは喉頭挙上 介助法を用いて誤嬹を防いだ。訓練開始から 4 日目に とろみ付の液体で遅延せずに嚥下反射が起こるように なり，ゼリーの直接嚥下訓練を開始した。嚥下反射が 起こらないときは喉頭挙上介助法を用いた。ゼリーで 遅延せずに嚥下反射が起こるようになり重度苝下食の 直接嚥下訓練を開始したのは, 10 日目であった。1 日目に咽喉頭での唾液の貯留音は完全に消失し，嚥下 反射が自発的に繰り返し起こるようになった。16日 目に，軽度嚥下食による直接嚥下訓練を開始した。 そ の後の29 日間訓練を継続したが, 軽度嚥下食から一 般の食事形態への変更は不能で, 介助なしでの摂食は 困難であった，そのため，退院に向けて ST から家族 へ口腔顔面筋群の筋力向上訓練, 食事形態, 食事介助 の指導を行った，摂食嚥下訓練後の身体機能は，ラン クC2 のままであった，発語は少ないが会話は可能に なった， 口腔周囲㧍よび口腔内所見については，舌・ 㚘部の運動範囲の軽度制限が見られたが口腔各器官の 繰り返し運動は容易となった。

入院中, 当院口腔ケアチームによる口腔ケアが行わ れた。 なお, 理学療法と作業療法は実施されなかった。

2006 年 9 月に退院し, 1 日 3 回のヘルパー, 週 1 回 の訪問看護, 週 2 回の訪問入浴, 2 週に 1 回のデイサー ビスを利用しながら自宅での生活を送っていたが，退 院から 1 年 6 カ月経過した 2008 年 3 月に残念ながら 誤嚥性肺炎を再発した。

\section{考察}

長期臥床により誤嚥性肺炎を繰り返していた超高齢 患者に対して燕下訓練を実施し, 経口摂取が可能にな り退院後も嚥下機能が長期間維持された。この症例に おいて, 嚥下訓練の早期開始, 喉頭挙上介助法を使っ た嚥下訓練，退院に向けての家族指導の 3 点が有効 だったと考える。

まず嚥下訓練の早期開始は, 唾液の誤嚥と嚥下機能 の悪化を止めるのに有効だったと考える、嚥下訓練は 入院 3 日目から開始したが,この時点で発熱は続い ており $\mathrm{SpO}_{2}$ は酸素吸入を行って $90 \%$ 台となる状態で あった。嚥下機能は低下しており，絶食となっても唾 液の誤嚥は続いていた。曣下機能の改善が得られなけ
れば誤燕は止まらず，與下訓練を開始しなければさら に嚥下機能が低下すると予想された。嚥下造影を待た ずに, 視診, 触診, 聴診を使って目燕下機能を確認しな がら嚥下訓練を開始した。

嚥下訓練においては，喉頭挙上介助法が本症例の嚥 下反射誘発に有効だった。空嚥下を指示した際に口唇 閉鎖までは自発的に行えたので，それに続く動きを促 すために喉頭挙上介助法を用いた。間接嚥下訓練の際 は，食べ物を用いずに喉頭を他動的に押し上げること で嚥下反射を起こした，直接嚥下訓練では，食べ物が 口腔内に入ってから下㕷や舌の動きと，ときどきは喉 頭の不十分な動きまでもが観察されるにもかかわらず 嚥下反射が起こらないときに喉頭を他動的に押し上げ て嚥下反射を起こした。喉頭挙上介助法により喉頭を 押し上げても，嚥下反射の際の喉頭挙上位置まで押し 上げることはできない，喉頭を押し上げた状態で維持 すると，鱟下反射が起こり甲状舌骨筋の収縮により喉 頭がさらに挙上する。嚥下反射は鼻咽腔の閉鎖，喉頭 の挙上，声門の閉鎖，咽頭管の蠕動的収縮と食道の入 口部の開大が再現性をもって発現する中枢性のパター ン運動である ${ }^{5}$. 喉頭の挙上維持はそのパターン運動 開始のトリガーになるのではないかと考える。

嚥下反射は食物が咽頭・品・峡柱・軟口蓋・喉頭蓋 の粘膜に触れることにより誘発される と市といわれてき た.しかし Palmerらの研究により，健常な成人の固 形食の燕下過程において燕下準備としての食塊形成が 口腔内で生じておらず，咀嚼された食物が口峡の間を 通って中咽頭へと送られ曣下に先立ってそこに蓄積さ れることが明らかとなった ${ }^{7)}$. 中咽頭に食物が送られ てもただちに嚥下反射は起こらないのである。また， Palmer らは, 食物の破砕と中咽頭への移送と咽頭嶼 下の間に顎，舌，舌骨，喉頭の運動が連動することを 観察した ${ }^{7)}$. 連動する各器官の運動に同期して嚥下反 射が起こるのである。これらの観察から，嚥下反射が 粘膜刺激だけで誘発されるとは考えがたい。むしろ連 動する運動パターンのなかに嚥下反射を誘発するトリ ガーがあるのではないだろうか. 喉頭挙上維持はこの 嚥下反射を誘発するトリガーの一つかもしれない。

本症例において喉頭挙上介助法が効果的であったの は，甲状舌骨筋の筋力低下により嚥下反射が起こりに くくなっていたためであろうと推測する，舌骨筋群の なかで甲状軟骨に付着する筋は甲状舌骨筋と胸骨甲状 筋の 2 つであり，甲状舌骨筋は舌骨が固定されたとき に甲状軟骨を引き上げる作用をもち胸骨甲状筋は甲状 軟骨を引き下げる作用をもつ。他の舌骨筋は舌骨の位 
置を変えたり固定する作用をもち，甲状軟骨の挙上を 補助するが直接引き上げる作用はない，甲状舌骨筋が 甲状軟骨を引き上げる際の筋収縮は，重力に抗して喉 頭を引き上げるものであり筋力を要する。，その筋力低 下は嚥下反射惹起を困難にしたのだろう。

退院にあたっては, 家族に対して口腔顔面筋群の筋 力向上訓練, 食事形態, 食事介助の指導を行ったが, これは退院後の嚥下機能維持と誤嬹防止に有効だった と考える。退院時も臥床状態であり活動性がきわめて 低い状態だったことから, 茧下機能維持のため口腔顔 面筋群の筋力が低下しないよう指導が必要だった。ま た安全に経口摂取を続けるためには，食事形態と食事 介助について説明することが必要だった。

超高齢嚥下障害患者の嚥下訓練経過と訓練において 有効であった手技などについて報告した。高齢社会白 書によると，後期高齢者人口は前期高齢者人口の伸び を上回る増加数で推移してきている8 . 前期高齢者人 口より後期高齢者人口が多くなるのは時間の問題だと もいわれている ${ }^{9)}$. 今後，與桼下訓練を必要とする後期 高齢者や超高齢者は増加するであろう。こういった症 例に対し，早期に介入して與萩下評価・訓練を進めてい くことが必要である.

謝辞：執筆にあたりご助言いただきました当院リハビリテー ション科 影近謙治先生ならびに歯科口腔外科 由良晋也先生に 感謝いたします。

\section{文献}

1）大内尉義 : 医学的観点から見た後期高齢者と前期高齢者の 違いについて。第 20 回社会保障審議会医療保険部会資料, 2005.

2) 大内尉義:臨床医に知ってほしい高齢者医療の特徵と課題. 日医杂誰誌, $135 ： 1253-1257,2006$.

3）山本真由美：廃用症候群患者の摂食機能障害に対する摂食 嚥下訓練の効果とその効果に影響する因子. 音声言語医学, $49: 7-13,2008$.

4）稲田晴生：造影検査に対するリスク管理について。嚥下障 害 Q \& A （吉田哲二編），医薬ジャーナル社，大阪，62-63 頁, 2001 .

5）梅崎俊郎：嚥下運動は反射なのか？ 嚥下障害 Q \& A （吉 田哲二編），医薬ジャーナル社，大阪，28-29 頁，2001.

6）山田好秋：よくわかる摂食・嬹下のメカニズム, 医歯薬出 版, 東京, 2004 .

7) Palmer JB and Hiiemae KM: Integration of oral and pharyngeal bolus propulsion: A new model for the physiology of swallowing. 摂食・嚥下リ八, 1: 15-30, 1997.

8）内閣府編：平成 19 年度高齢社会白書, ぎょうせい, 2007.

9）大内尉義：高齢社会に求められる総合医療. 日本病院会䧱 誌, 53：990-999, 2006.

別刷請求先：テ939-1395 富山県砺波市新富町 1-61 市立砺波総合病院総合リハビリテーション センター 山本真由美 